\title{
Macronutrient and sodium content in maize plants under cassava wastewater fertilization
}

\author{
Adriana G. Magalhães ${ }^{1}$, Mario M. Rolim ${ }^{1}$, Anamaria de S. Duarte ${ }^{1}$, \\ Gerônimo F. da Silva ${ }^{1}$, Egídio Bezerra Neto ${ }^{1}$ \& Elvira M. R. Pedrosa ${ }^{1}$ \\ ${ }^{1}$ Universidade Federal Rural de Pernambuco/Departamento de Engenharia Agrícola. Recife, PE. E-mail: agmguedes@gmail.com; mario.rolim@ufrpe.br \\ (Corresponding author); asousaduarte@gmail.com; agrogefe@yahoo.com.br; egidiobn@yahoo.com.br; elvira.pedrosa@ufrpe.br
}

\section{Key words:}

Zea mays

residue reuse

mineral nutrition

\begin{abstract}
A B S T R A C T
This study aimed to evaluate the content of macronutrients and sodium in corn (Zea mays) plants as a function of different doses of cassava wastewater and ages of the plants after emergence. The experiment was conducted in a greenhouse in pots with capacity for 25 $\mathrm{dm}^{3}$ of soil, using a $5 \times 3$ factorial design with four replicates. The studied factors were doses of cassava wastewater: $0 ; 12.6 ; 25.2 ; 50.4 ; 75.6 \mathrm{~m}^{3} \mathrm{ha}^{-1}$, and plant age: 20,40 and 52 days after emergence (DAE). Potassium, calcium, magnesium, nitrogen, phosphorus, sodium and sulfur contents were evaluated in leaves and stalks. Nutritional deficiency of calcium was visible at $20 \mathrm{DAE}$. The increment in cassava wastewater doses increased $\mathrm{N}, \mathrm{P}$ and $\mathrm{K}$ contents in plant shoots, but decreased $\mathrm{Ca}$ and $\mathrm{Mg}$ absorption. The contents of $\mathrm{N}, \mathrm{P}$ and $\mathrm{K}$ in the leaves and $\mathrm{N}$ in stalks at $20 \mathrm{DAE}$ were higher than at 40 and $52 \mathrm{DAE}$. The highest contents of $\mathrm{P}$ and $\mathrm{K}$ in the stalks occurred at 40 DAE.
\end{abstract}

\section{Palavras-chave:}

Zea mays

reaproveitamento de resíduos nutrição mineral

\section{Teores de macronutrientes e sódio em plantas de milho biofertilizadas com manipueira}

\begin{abstract}
R E S U M O
Objetivou-se, com este trabalho, avaliar os teores de macronutrientes e sódio em plantas de milho (Zea mays) em função da aplicação de doses de manipueira e idade das plantas após a emergência. $\mathrm{O}$ experimento foi conduzido em casa de vegetação em vasos com capacidade de $25 \mathrm{dm}^{3}$ de solo usando o esquema fatorial $5 \times 3$ com quatro repetições. Os fatores de estudo foram doses de manipueira: $0 ; 12,6 ; 25,2 ; 50,4 ; 75,6 \mathrm{~m}^{3} \mathrm{ha}^{-1}$ e idade das plantas aos 20, 40 e 52 dias após a emergência (DAE). Foram avaliados, nas folhas e no colmo, os teores de nitrogênio, fósforo, potássio, cálcio, magnésio, enxofre e sódio. Aos 20 DAE as plantas apresentaram deficiência nutricional em cálcio. $\mathrm{O}$ incremento das doses de manipueira aplicadas no solo aumentou os teores de N, P e K na parte aérea das plantas e reduziu a absorção de $\mathrm{Ca}$ e $\mathrm{Mg}$. Os teores de $\mathrm{N}$, P e K nas folhas e de $\mathrm{N}$ nos colmos das plantas de milho, aos $20 \mathrm{DAE}$, foram maiores que aos 40 e $52 \mathrm{DAE}$. Os maiores teores de $\mathrm{P}$ e $\mathrm{K}$ foram registrados nos colmos aos $40 \mathrm{DAE}$.
\end{abstract}




\section{INTRODUCTION}

In agriculture, the use of properly treated organic residues allows increasing the contents of carbon and nutrients in the soil, increasing its cation exchange capacity and $\mathrm{pH}$. In this aspect, increments in the contents of organic matter and nutrients in the soil, due to the use of these residues, improve physical and chemical properties and, consequently, yield and quality of products, decreasing production costs (Laufenberg et al., 2003).

Cassava wastewater is one of the residues generated in the processing of cassava (Manihot esculenta Crantz) for obtaining the flour or starch. The reuse of this residue as an agricultural biofertilizer, according to Silva Júnior et al. (2012), is viable due to the high content of organic matter and the presence of various nutrients essential to plants, such as nitrogen, phosphorus, potassium, calcium, magnesium, copper, zinc and manganese; besides contributing efficiently to the reduction of damages to the environment, because its composition has high organic load and concentration of hydrocyanic gas, which are potential environmental pollutants.

Studies related to the use of cassava wastewater in the cultivation of other crops have also been reported by other authors. Duarte et al. (2012), studying the effect of using cassava wastewater on the lettuce crop (Lactuta sativa L.), concluded that it served as source of fertilization for the crop; however, adequate doses were necessary in order to avoid the deleterious effect of some nutrients, especially potassium, the ion found in highest concentration in the cassava wastewater. In the study, these authors mention that the dose of $45 \mathrm{~m}^{3} \mathrm{ha}^{-1}$ promoted the best plant development. Similar responses were obtained by Ribas et al. (2010) and Inoue et al. (2011).

In the evaluation of corn (Zea mays L.)fertigated with treated cassava wastewater, Saraiva et al. (2007) observed increase in the contents of organic matter, calcium and magnesium in the soil, and phosphorus and zinc in leaf tissues and roots.

To establish an adequate nutrition for plants, the knowledge on the amount of nutrients, relationship between nutrients and normal patterns of accumulation in the dry matter and over the cultivation time is of fundamental importance, because it will allow the quantification of the nutrients necessary for production, as well as the period of highest demand, the organ each with the highest amount of the nutrient, the amount exported by the harvest and the amount to be replenished to the soil in order not to deplete it (Damasceno et al., 2012). However, the amount and proportionality of nutrients absorbed by plants are a function of intrinsic characteristics of the plants and the external factors that condition the process. The capacity of the species to remove nutrients from the soil and the required amounts vary not only with the cultivar, but also with the existing degree of competition. Variations in the environmental factors, such as temperature and soil moisture, may considerably affect the contents of mineral nutrients in the leaves. These factors influence both the availability and the absorption of these nutrients by the roots and shoot growth. On the other hand, the accumulation and distribution of mineral nutrients in the plant depend on its development stage (Goto et al., 2001).
In turn, corn plants have fast and continuous growth, with accumulation of nutrients and dry matter in all reproductive stages. There is a great demand in the supply of water and nutrients to meet plant requirements, because crop production and yield are associated with the number of grains per row in each ear, whose maximum length is conditioned by the good availability of water and nutrients (Magalhães, 2013).

Crop nutritional requirements are determined by the amount of nutrients that plants are able to extract from the soil (Ueno et al., 2011). This extraction depends on the obtained yield and the accumulation of nutrients in the grains and in other plant parts. Thus, its knowledge is of fundamental importance to subsidize strategies to define the amount of fertilizations and the minimum amounts that must be replenished to the soil, in order to maintain the fertility (Pinho et al., 2009).

This study aimed to evaluate the contents of macronutrients in corn plants as a function of the application of doses of cassava wastewater and collection periods.

\section{Material ANd Methods}

The experiment was carried out in pots with capacity for $25 \mathrm{dm}^{3}$ of soil from November 2011 to February 2012, in a greenhouse, at the Department of Agricultural Engineering of the Federal Rural University of Pernambuco, Recife-PE, Brazil. The soil used in the experiment was collected at the Agronomic Institute of Pernambuco (IPA), in the municipality of Itambé-PE, in the layer of $0-20 \mathrm{~cm}$, and the texture was characterized as clay loam.

Before incorporating the cassava wastewater, three individual soil samples were collected to form a composite sample, which was air-dried, pounded to break up clods and sieved through a $2-\mathrm{mm}$ mesh, for the determination of physical and chemical characteristics (Table 1) according to the methodology proposed by EMBRAPA (2009).

The cassava wastewater used in the experiment came from a flour mill located in the municipality of Pombos-PE and its physical and chemical composition (Table 2) was determined at the Laboratories of Environmental Engineering and Quality (LEAQ) and Soil Mechanics and Residues Use of UFPE and UFRPE, respectively. Physical and chemical parameters were determined according to the methodology proposed by APHA (1995).

Each pot used in the experiment was filled with $20 \mathrm{~kg}$ of soil. In order to allow the drainage of the excess irrigation water, a 5 -cm-thick layer of crushed stone $\left(n^{\circ} 0\right)$ was added

Table 1. Soil physical and chemical characteristics before the experiment

\begin{tabular}{lc}
\hline \multicolumn{1}{c}{ Parameters } & Content \\
\hline Sand $\left(\mathrm{g} \mathrm{kg}^{-1}\right)$ & 660.0 \\
Silt $\left(\mathrm{g} \mathrm{kg}^{-1}\right)$ & 36.8 \\
Clay $\left(\mathrm{g} \mathrm{kg}^{-1}\right)$ & 303.2 \\
ECse $\left(\mathrm{dS} \mathrm{m}^{-1}\right)$ & 0.30 \\
pH in water & 5.50 \\
Phosphorus $\left(\mathrm{mg} \mathrm{dm}^{-3}\right)$ & 12.68 \\
Potassium $\left(\mathrm{cmol}_{\mathrm{c}} \mathrm{dm}^{-3}\right)$ & 0.27 \\
Calcium $\left(\mathrm{cmol}_{\mathrm{c}} \mathrm{dm}^{-3}\right)$ & 1.65 \\
Magnesium $\left(\mathrm{cmol}_{\mathrm{c}} \mathrm{dm}^{-3}\right)$ & 1.25 \\
Sodium $\left(\mathrm{cmol}_{\mathrm{c}} \mathrm{dm}^{-3}\right)$ & 0.03 \\
\hline
\end{tabular}


Table 2. Physical and chemical characteristics of the cassava wastewater

\begin{tabular}{lc}
\hline \multicolumn{1}{c}{ Parameters } & Content \\
COD $\left(\mathrm{mg} \mathrm{L}^{-1}\right)$ & $119,220.40$ \\
Electrical conductivity $\left(\mathrm{dS} \mathrm{m}^{-1}\right)$ & 9.61 \\
$\mathrm{pH}$ & 6.83 \\
Potassium $\left(\mathrm{mg} \mathrm{L}^{-1}\right)$ & $4,793.90$ \\
Phosphorus $\left(\mathrm{mg} \mathrm{L}^{-1}\right)$ & 286.40 \\
Magnesium $\left(\mathrm{mg} \mathrm{L}^{-1}\right)$ & $1,588.20$ \\
Sodium $\left(\mathrm{mg} \mathrm{L}^{-1}\right)$ & 742.00 \\
Calcium $\left(\mathrm{mg} \mathrm{L}^{-1}\right)$ & 241.90 \\
\hline
\end{tabular}

CDO - Chemical oxygen demand

to each pot and covered by a geotextile $\left(\operatorname{Bidim}^{\oplus}\right)$, to avoid possible soil losses.

After preparing the pots, as previously described, three pots were saturated through capillarity and daily weighed until constant weight, in order to estimate the container capacity. Then, the mean weight of the three pots with soil at container capacity was determined.

Since all the pots used in the experiment were filled in the same way, the volume of water necessary for each plant was obtained by the difference of the mean weight with soil at container capacity and the weight of each one of these pots containing one plant, which were measured every day. Irrigation was performed based on the container capacity and, for this, tests of weighings of the pots were carried out.

The tested crop was corn, hybrid AG 1051 from Agroceres, which was developed for the production of green corn and silage, and has semi-early cycle, on average, 115 days for ensilage and 144 days for grain harvest, high production of grains and fresh matter with good digestibility.

Sowing was performed 20 days after the cassava wastewater was applied in the soil. In each pot, three seeds were planted at the depth of $1 \mathrm{~cm}$. After germination, thinning was performed, leaving one plant per pot. Cultivation lasted for 52 days, a period in which, according to Fancelli \& Dourado Neto (2000), the plant has ten pairs of fully expanded leaves and precedes the emergence of the tassel.

The experimental design was completely randomized, in $5 \times$ 3 factorial scheme with four replicates, totaling 60 experimental plots. The studied factors were: cassava wastewater doses, $0 ; 12.6$; 25.2; 50.4; $75.6 \mathrm{~m}^{3} \mathrm{ha}^{-1}$, and collection periods, 20,40 and 52 days after emergence (DAE). The doses of cassava wastewater were determined taking into consideration the potassium content in the soil, its concentration in the cassava wastewater and its requirement by the corn crop, $20 \mathrm{~kg} \mathrm{ha}^{-1}$, according to IPA (2008). Liming was not necessary and, in order to evaluate only the effect of using cassava wastewater on the crop, mineral fertilization was not used during the experiment.

For each studied period, 20, 40 and 52 DAE, plant shoots were collected, divided into leaves and stalk, placed in previously identified paper bags and dried in a forced-air oven at $65{ }^{\circ} \mathrm{C}$ for $72 \mathrm{~h}$. The dried samples were ground in a Wiley-type mill and subjected to sulfuric digestion for the determination of nitrogen $(\mathrm{N})$ and nitric-perchloric for the determination of phosphorus $(\mathrm{P})$, potassium $(\mathrm{K})$, calcium $(\mathrm{Ca})$, magnesium $(\mathrm{Mg})$, sulfur $(\mathrm{S})$ and sodium $(\mathrm{Na})$, according to Bezerra Neto \& Barreto (2011).
The data were subjected to analysis of variance and, when effects of treatments were observed, also subjected to linear regression analysis, both at 0.05 probability level.

\section{Results AND Discussion}

The mean contents of $\mathrm{N}, \mathrm{P}, \mathrm{K}, \mathrm{Ca}$ and $\mathrm{Mg}$ in corn shoots at 20, 40 and 52 days after emergence (DAE), as a function of doses of cassava wastewater applied to the soil are shown in Figures 1 to 5. At $20 \mathrm{DAE}, \mathrm{N}$ contents in the leaves (Figure 1A) and in the stalk (Figure 1B) showed similar behavior in relation to the applied doses of cassava wastewater, and this behavior diverged at 40 and $52 \mathrm{DAE}$, compared with the behavior at 20 DAE (Figures $1 \mathrm{~A}$ and $1 \mathrm{~B}$ ).

At 20 DAE, $\mathrm{N}$ contents in corn leaves and stalks showed a positive quadratic response; the lowest $\mathrm{N}$ contents, $10.99 \mathrm{~g} \mathrm{~kg}^{-1}$ in the leaves and $4.33 \mathrm{~g} \mathrm{~kg}^{-1}$ in the stalks, were observed for the absence of cassava wastewater $\left(0 \mathrm{~m}^{3} \mathrm{ha}^{-1}\right)$ and the highest $\mathrm{N}$ contents, $44.06 \mathrm{~g} \mathrm{~kg}^{-1}$ in the leaves (Figure 1A) and $36.73 \mathrm{~g} \mathrm{~kg}^{-1}$ in the stalks (Figure 1B) respectively, at the doses of 52.5 and $48.1 \mathrm{~m}^{3} \mathrm{ha}^{-1}$ of cassava wastewater.

Very important to plants, $\mathrm{N}$ is an essential constituent of aminoacids and one of the main components of proteins, besides participating in cell division and chlorophyll production (Malavolta et al., 1997). According to these authors, there is an intense participation of $\mathrm{N}$ in physiological processes and metabolic activities of plants, in the initial development stage, corroborating the responses found in the present study for $20 \mathrm{DAE}$.

In the other two periods, 40 and $52 \mathrm{DAE}$, the trend observed for $\mathrm{N}$ contents in the leaves and stalks was contrary to that at 20

A.

$$
\begin{array}{r}
Y=10.99+1.26 x-0.012 x^{2} R^{2}=0.86(20 D A E) \\
Y=25.05-0.26 x+0.003 x^{2} R^{2}=0.65(40 D A E) \\
Y=19.63-0.38 x+0.005 x^{2} R^{2}=0.60(52 D A E)
\end{array}
$$

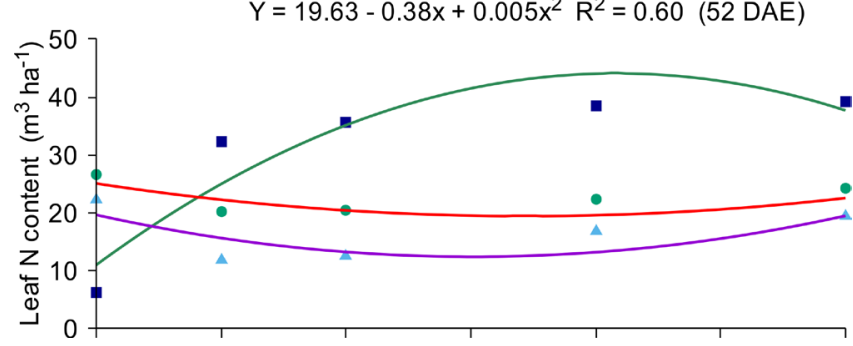

B.

$$
\begin{aligned}
& Y=4.332+1.347 x-0.014 x^{2} R^{2}=0.86(20 D A E) \\
& Y=9.014+0.106 x R^{2}=0.83(40 D A E) \\
& Y=1.51+0.324 x-0.004 x^{2} \quad R^{2}=0.73(52 D A E)
\end{aligned}
$$

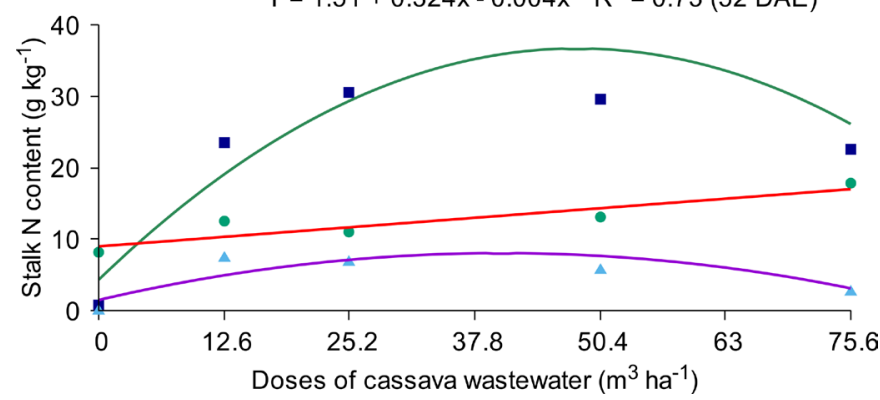

Figure 1. Mean content of nitrogen $(\mathrm{N})$ at 20,40 and 52 days after emergence (DAE) in corn leaves (A) and stalks (B) as a function of doses of cassava wastewater applied to the soil 
DAE; there were lower contents of the elements in both plant parts and regression models differed from those at 20 DAE. At 40 and 52 DAE, a negative quadratic effect was observed for the $\mathrm{N}$ contents in the leaves as a function of the increment in the doses of cassava wastewater applied to the soil. At 40 DAE, in the absence $\left(0 \mathrm{~m}^{3} \mathrm{ha}^{-1}\right)$ and presence of the highest doses of cassava wastewater $\left(75 \mathrm{~m}^{3} \mathrm{ha}^{-1}\right)$, the $\mathrm{N}$ contents in the leaves were 25.05 and $20.61 \mathrm{~g} \mathrm{~kg}^{-1}$, respectively. However, the lowest $\mathrm{N}$ content $\left(20.51 \mathrm{~g} \mathrm{~kg}^{-1}\right)$ was obtained at $50.4 \mathrm{~m}^{3} \mathrm{ha}^{-1}$ of the residue. At $52 \mathrm{DAE}$, the trend was the same as in the previous period, with the lowest $\mathrm{N}$ content in the leaves $\left(13.31 \mathrm{~g} \mathrm{~kg}^{-1}\right)$ at $50.4 \mathrm{~m}^{3} \mathrm{ha}^{-1}$.

As to the $\mathrm{N}$ contents in the stalks as a function of the applied doses of cassava wastewater at $40 \mathrm{DAE}$, the data showed positive linear response, while at $52 \mathrm{DAE}$, the response was positive quadratic (Figure 1B); at $40 \mathrm{DAE}, \mathrm{N}$ content in the stalks, for the highest doses of cassava wastewater, was $17.08 \mathrm{~g} \mathrm{~kg}^{-1}$ and, at $52 \mathrm{DAE}$, the application of $53.06 \mathrm{~m}^{3} \mathrm{ha}^{-1}$ of cassava wastewater promoted the highest $\mathrm{N}$ content in the stalks $\left(7.52 \mathrm{~g} \mathrm{~kg}^{-1}\right)$.

The decrease in $\mathrm{N}$ contents in the leaves and stalks occurred at 40 and $52 \mathrm{DAE}$, in relation to $20 \mathrm{DAE}$, is probably associated with the formation of masculine inflorescence, because in this period the nutrients stored in the stalk are distributed to the leaves, which make them available for the development of flower organs (Magalhães, 2013).

At $20 \mathrm{DAE}$, the observed leaf $\mathrm{N}$ contents were considered as adequate; on the other hand, at 40 and 52 DAE, such contents remained below the values considered as adequate for the corn crop (27.5 to $32.5 \mathrm{~g} \mathrm{~kg}^{-1}$ ), according to IPA (2008). In spite of that, no visual symptoms of deficiency were observed in the plants.

Evaluating the effect caused by the application of treated cassava wastewater on corn development, Ribas et al. (2010) observed that the $\mathrm{N}$ content in the leaf tissues of plants that received cassava wastewater was superior to that in the control treatment, at $37 \mathrm{DAE}$, but these contents remained below those considered as adequate for the corn crop, according to IPA (2008), which was also observed in the present study. On the other hand, Inuoe et al. (2011) reported no increase in leaf $\mathrm{N}$ content in corn plants due to the increment in the doses of treated cassava wastewater.

Working with other residues, Costa et al. (2012) applied increasing doses of domestic effluent and obtained increase in the $\mathrm{N}$ contents in the leaves, which indicates the efficiency of domestic effluent as a source of $\mathrm{N}$ to plants. Similar response was obtained by Gomes et al. (2007) in the cultivation of corn fertilized with sewage sludge, but these authors point out that this residue, despite promoting higher $\mathrm{N}$ absorption by plants, did not provided good nutritional condition.

According to the regression models that best fitted to the data of $\mathrm{P}$ contents in the leaves and stalks (Figures $2 \mathrm{~A}$ and $2 \mathrm{~B}$ ), except for leaf $\mathrm{P}$ contents at $40 \mathrm{DAE}$, the trend showed by this nutrient, both in leaves and stalks, was similar to that of $\mathrm{N}$.

The application of cassava wastewater to the soil promoted positive quadratic effect on $P$ contents in the leaves at $20 \mathrm{DAE}$, increasing linear effect at $40 \mathrm{DAE}$ and negative quadratic effect at $52 \mathrm{DAE}$ (Figure 2A). The maximum $\mathrm{P}$ content in the leaves,
A.
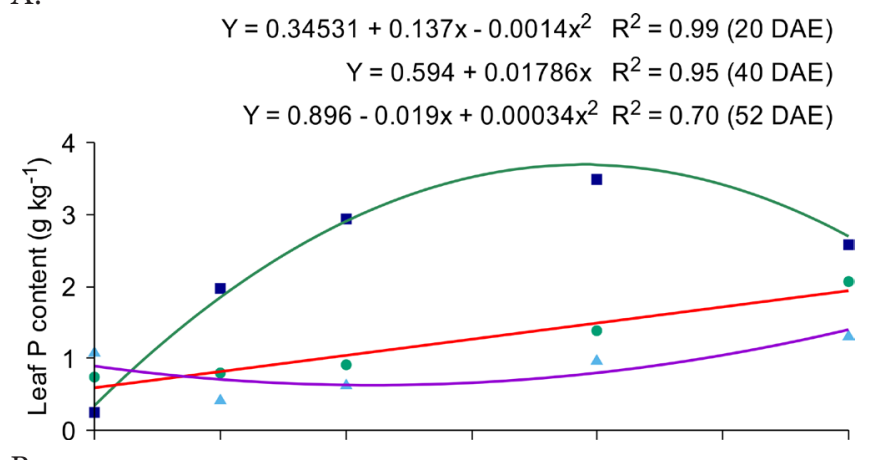

B.

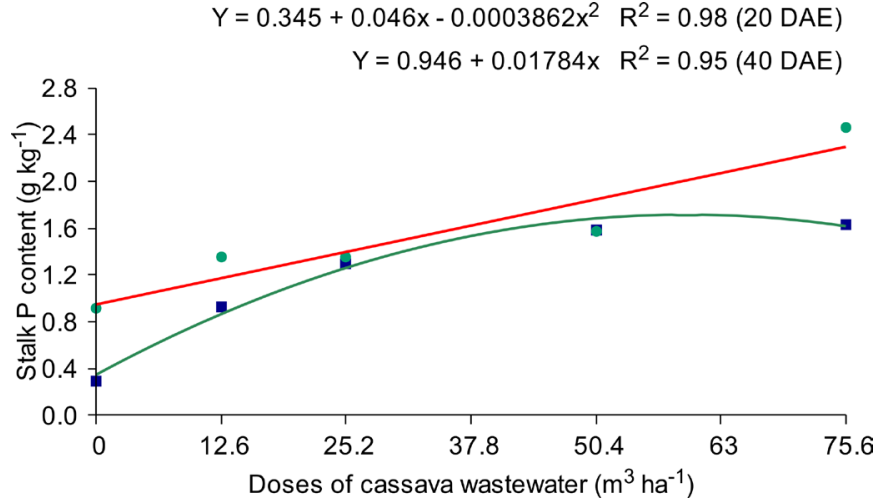

Figure 2. Mean contents of phosphorus $(P)$ in corn leaves at 20, 40 and 52 days after emergence (DAE) (A) and in stalks at 20 and 40 DAE (B) as a function of doses of cassava wastewater applied to the soil

at $20 \mathrm{DAE}$, was $3.69 \mathrm{~g} \mathrm{~kg}^{-1}$, which was obtained at $48.93 \mathrm{~m}^{3} \mathrm{ha}^{-1}$. Values of 1.94 and $1.38 \mathrm{~g} \mathrm{~kg}^{-1}$ were observed, respectively, at 40 and $52 \mathrm{DAE}$, due to the application of $75.6 \mathrm{~m}^{3} \mathrm{ha}^{-1}$ of cassava wastewater. This shows high exportation of this nutrient by plants during the development period.

As to the $\mathrm{P}$ contents in corn stalks, the behavior was similar to that of $\mathrm{P}$ in the leaves; however, at $20 \mathrm{DAE}$, the $\mathrm{P}$ contents in the stalks was lower than in the leaves, and the response was inverted at $40 \mathrm{DAE}$ (Figure 2B); at $20 \mathrm{DAE}$, the minimum and maximum $P$ contents in the stalks were equal to 0.34 and 1.71 $\mathrm{g} \mathrm{kg}^{-1}$ for the doses of 0 and $59.55 \mathrm{~m}^{3} \mathrm{ha}^{-1}$, respectively, which evidences an increase of $80.1 \%$ due to the increment in the doses of the residue (Figure $2 \mathrm{~B}$ ). The fact that $\mathrm{P}$ contents in the stalk were lower than those in the leaves can be related to translocation in the plant during the development period. At $40 \mathrm{DAE}$, higher amount of $\mathrm{P}$ was removed by plants, because the highest doses of cassava wastewater applied to the soil $\left(75.6 \mathrm{~m}^{3} \mathrm{ha}^{-1}\right)$ promoted the highest content of this nutrient $\left(2.29 \mathrm{~m}^{3} \mathrm{ha}^{-1}\right)$ in the stalks. This probably indicates that corn does not demand large amounts of phosphorus during this stage of development.

The $\mathrm{P}$ contents in plant leaf tissue were considered as adequate only at 20 DAE. According to IPA (2008), adequate $\mathrm{P}$ contents in the leaf tissue of corn plants must range between 2.5 and $3.5 \mathrm{~g} \mathrm{~kg}^{-1}$.

Evaluating the development, yield and contents of macronutrients in millet and Sudan grass, subjected to the application of doses of whey in the soil, Morrill et al. (2012) obtained $\mathrm{P}$ values superior to those in the control, and adequate for corn (2.5 to $3.5 \mathrm{~g} \mathrm{~kg}^{-1}$ ) and sorghum (4.0 to $8.0 \mathrm{~g} \mathrm{~kg}^{-1}$ ), 
according to IPA (2008). Erthal et al. (2010), studying the application of cattle-raising wastewater in the soil, observed that the $\mathrm{P}$ contents in the evaluated forages (Tifton 85 grass and black oat) was superior to that obtained in the control. However, Inoue et al. (2011) evaluated the contents of nutrients in corn plants fertilized with biofertilizer (cassava wastewater and cassava hulls) and observed no significant difference in the total $\mathrm{P}$ content in the shoots, although the concentration of $\mathrm{P}$ in the biofertilizer was 10 times higher than that used in the present study.

The potassium contents, in the first 20 days of crop development, increased as the applied doses of cassava wastewater increased (Figure 3A), and the ideal estimated dose was $43.83 \mathrm{~m}^{3} \mathrm{ha}^{-1}$, which is equivalent to a content of $54.83 \mathrm{~g} \mathrm{~kg}^{-1}$, decreasing from this dose on.

At $40 \mathrm{DAE}$, the application of cassava wastewater to the soil promoted increasing linear effect on leaf $\mathrm{K}$ contents (Figure 3A), with 31.59 and $39.22 \mathrm{~g} \mathrm{~kg}^{-1}$ for the absence and presence of the highest dose of cassava wastewater, respectively. At 52 DAE, leaf $\mathrm{K}$ contents did not differ significantly between treatments.

In the same period, plants cultivated in the soil that received the highest dose of cassava wastewater $\left(75.6 \mathrm{~m}^{3} \mathrm{ha}^{-1}\right)$ showed low germination and burn on the tip of the leaves, indicating that there might have been intolerance to the high content of this nutrient, reflecting in a toxic effect to plants. Thus, it is expected that a longer rest period for the residue could possibly have promoted a more efficiency germination.

In the stalks, at $20 \mathrm{DAE}$, the trend observed for $\mathrm{K}$ contents was similar to that in the leaves (Figure $3 \mathrm{~B}$ ) and the maximum

A.

$$
\begin{array}{r}
Y=10.65+2.016 x-0.023 x^{2} \quad R^{2}=0.93(20 \mathrm{DAE}) \\
Y=31.59+0.101 x \quad R^{2}=0.96(40 \mathrm{DAE})
\end{array}
$$

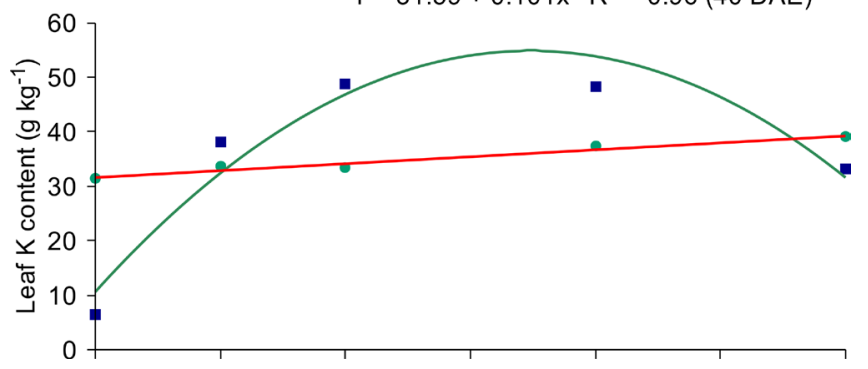

B.

$$
\begin{aligned}
Y=10.06+0.964 x-0.009 x^{2} & R^{2}=0.98(20 \mathrm{DAE}) \\
Y=28.12+1.355 x-0.009 x^{2} & R^{2}=0.93(40 \mathrm{DAE}) \\
Y=26.84+0.318 x & R^{2}=0.83(52 \mathrm{DAE})
\end{aligned}
$$

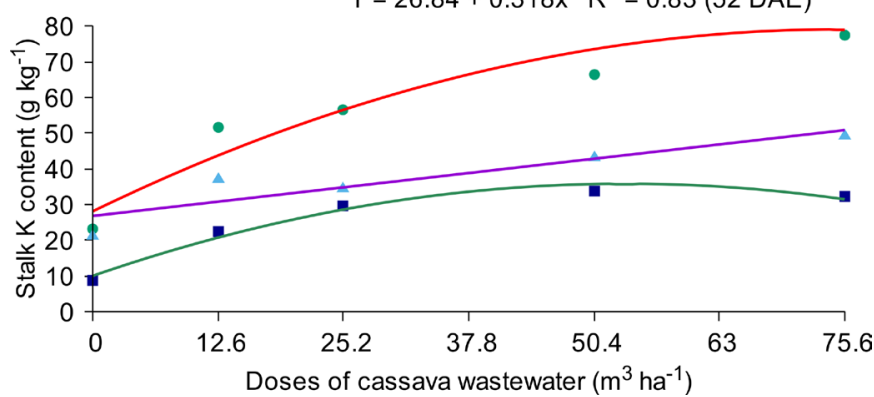

Figure 3. Mean contents of potassium (K) in corn leaves at 20 and 40 days after emergence (DAE) (A) and stalks at 20, 40 and 52 DAE (B) as a function of doses of cassava wastewater applied to the soil value $\left(35.86 \mathrm{~g} \mathrm{~kg}^{-1}\right)$ was obtained at the dose of $53.55 \mathrm{~m}^{3} \mathrm{ha}^{-1}$ (Figure 3B).

Studying the effect of the increasing $\mathrm{KCl}$ doses on corn germination and initial growth, Sangoi et al. (2009) also observed reduction in germination and initial growth, because the cultivated soil shows low $\mathrm{K}$ buffering power (KBP), low cation exchange capacity (CEC) and low content of organic matter, due to the high content of sand and low content of clay, which decreased the electrostatic adsorption of $\mathrm{K}$ due to the low CEC.

At 52 DAE, $\mathrm{K}$ content in the stalks (Figure 3B) showed response similar to that in the leaves at $40 \mathrm{DAE}$; in the absence of cassava wastewater the mean content was $26.84 \mathrm{~g} \mathrm{~kg}^{-1}$ and, in the presence of the highest dose of the residue $\left(75.6 \mathrm{~m}^{3} \mathrm{ha}^{-1}\right)$, the mean content was $50.89 \mathrm{~g} \mathrm{~kg}^{-1}$. At $40 \mathrm{DAE}$, the effect caused on $\mathrm{K}$ contents in the stalks was positive quadratic. The $\mathrm{K}$ content in the stalks at $40 \mathrm{DAE}$ was superior to those found in the other periods and the maximum content of the nutrient $\left(79.12 \mathrm{~g} \mathrm{~kg}^{-1}\right)$ was obtained with the application of the maximum physical efficiency dose of $75.27 \mathrm{~m}^{3} \mathrm{ha}^{-1}$ of cassava wastewater in the soil.

The results corroborate the observations of Ueno et al. (2011), who reported that maximum $\mathrm{K}$ absorption by corn plants occurs in the period of 30 to 40 days after germination, even if its absorption exceeds the absorption of $\mathrm{N}$ and $\mathrm{P}$, which suggests higher K requirement in the initial development stage of corn plants. The decrease in $\mathrm{K}$ contents in the stalks, between 40 and $52 \mathrm{DAE}$, is probably related to the redistribution of the nutrients used for the development of flower organs.

According to Rodrigues et al. (2014), K has great impact on the quality of the corn crop, with positive influence on the individual mass of grains and number of grains per ear, which evidences that the increase in crop yield depends, among other factors, on the increase in the absorption of the nutrient. Still according to the previously mentioned authors, after $\mathrm{N}, \mathrm{K}$ is the element absorbed in highest amount by corn and $30 \%$ is exported in the grains, which would explain the observed decrease. Evaluating the accumulation, extraction and dynamics of absorption of macronutrients by the corn crop, Borin et al. (2010) observed higher K accumulation in the first 30 days of plant development and the increasing accumulation occurred until 45 days after sowing, followed by a decrease caused by the redistribution to the ear.

According to IPA (2008), the K content in the leaf tissue of corn plants considered as adequate must be between 17.5 and $22.5 \mathrm{~g} \mathrm{~kg}^{-1}$. Thus, it is inferred that the content of this nutrient in the leaf tissue of plants cultivated in this experiment was superior to those considered as adequate, evidencing the great supply of $\mathrm{K}$ from the cassava wastewater applied to the soil.

The responses observed in the present study differ from those found by Saraiva et al. (2007) and by Inoue et al. (2011), who reported that $\mathrm{K}$ from treated cassava wastewater was not sufficient to maintain adequate levels of this nutrient in the leaf tissues of the plants, which is justified by the fact that part of the $\mathrm{K}$ contained in the cassava wastewater was lost when the residue was treated. In addition, this nutrient was found at concentrations much lower than in the cassava wastewater used in the present study (Table 2). Unlike the response of $\mathrm{K}$, 
the increase in the cassava wastewater doses promoted decrease in the Ca contents in plant shoots in the three studied periods (Figure 4A) and in the stalk, at 52 DAE (Figure 4B).

For the $\mathrm{Ca}$ contents in the leaves, the maximum values occurred in the absence of cassava wastewater in the soil, with values of $1.27,1.37$ and $1.48 \mathrm{~g} \mathrm{~kg}^{-1}$ at 20,40 and $52 \mathrm{DAE}$, respectively. However, the application of doses equal to $75.6 \mathrm{~m}^{3} \mathrm{ha}^{-1}$ at 20,40 and $52 \mathrm{DAE}$ promoted the respective decreases of $30 \%$ at $20 \mathrm{DAE}$ and $14 \%$ at $40 \mathrm{DAE}$. The dose of $54.67 \mathrm{~m}^{3} \mathrm{ha}^{-1}$ of cassava wastewater promoted the lowest Ca contents in the leaves $\left(0.68 \mathrm{~g} \mathrm{~kg}^{-1}\right)$ at $52 \mathrm{DAE}$ (Figure $4 \mathrm{~A}$ ).

As to the Ca contents in the stalks, at $20 \mathrm{DAE}$, the trend was similar to that in the leaves in the same period; however, at $40 \mathrm{DAE}$, the increase in the doses promoted a positive quadratic effect on the Ca content. At 20 DAE, the maximum and minimum contents of $\mathrm{Ca}$ in the stalks were equal to 0.36 and $0.21 \mathrm{~g} \mathrm{~kg}^{-1}$, obtained at the doses of 0 and $75.6 \mathrm{~m}^{3} \mathrm{ha}^{-1}$, respectively.

At 20 and $52 \mathrm{DAE}$, the $\mathrm{Mg}$ contents in the leaves of corn plants showed a decreasing linear response, while at $40 \mathrm{DAE}$ the trend was contrary to that at $20 \mathrm{DAE}$ (Figure 5).

During the first $20 \mathrm{DAE}$ and in the absence of application of cassava wastewater in the soil, the maximum $\mathrm{Mg}$ content in the leaves was $3.03 \mathrm{~g} \mathrm{~kg}^{-1}$ and the minimum content in the same period was $1.44 \mathrm{~g} \mathrm{~kg}^{-1}$, which was observed at $75.6 \mathrm{~m}^{3} \mathrm{ha}^{-1}$ of cassava wastewater (Figure 5). On the other hand, at 52 DAE and in the absence of cassava wastewater application, the maximum $\mathrm{Mg}$ content in the leaves was $2.96 \mathrm{~g} \mathrm{~kg}^{-1}$ and the minimum content in the same period was $2.01 \mathrm{~g} \mathrm{~kg}^{-1}$, observed with the application of the cassava wastewater dose of $75.6 \mathrm{~m}^{3} \mathrm{ha}^{-1}$. As to the $\mathrm{Mg}$ contents in the

A.



B.

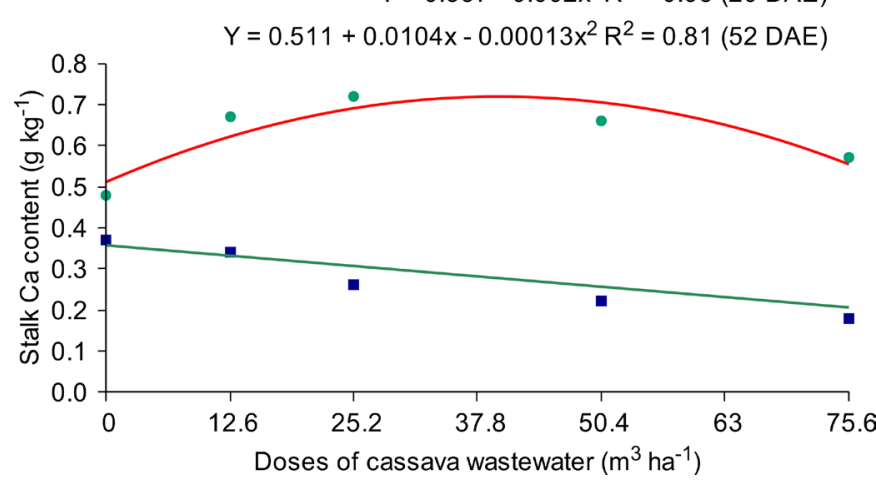

Figure 4. Calcium (Ca) contents in corn leaves at 20, 40 and 52 DAE (A) and stalks at 20 and 52 DAE (B) as a function of the applied doses of cassava wastewater

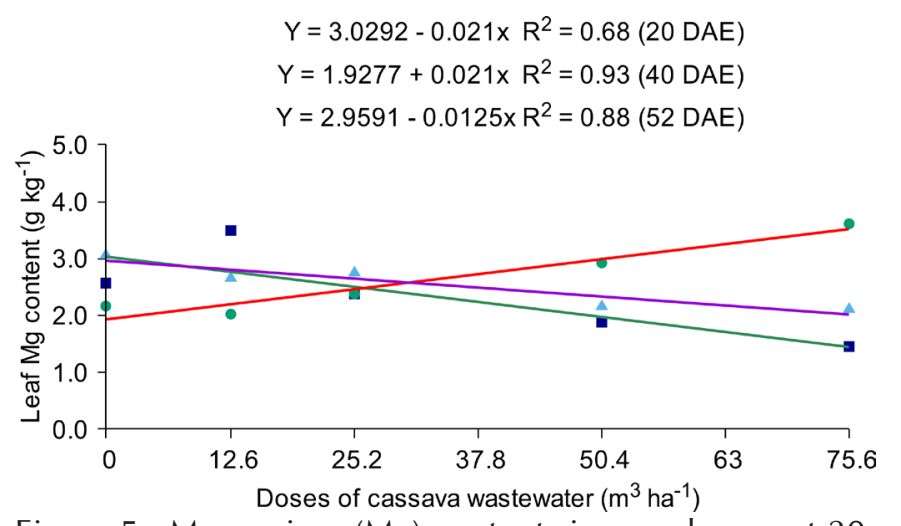

Figure 5. Magnesium (Mg) contents in corn leaves at 20, 40 and 52 days after emergence (DAE), as a function of the applied doses of cassava wastewater

stalk, no significant effects were observed for this variables as a function of the studied treatments.

It is important to observe that the highest $\mathrm{Mg}$ content in the leaves occurred at $40 \mathrm{DAE}$, as observed for the K content. However, in general, Ca absorption decreased in all the evaluation periods, evidencing that the increase in cassava wastewater doses harmed $\mathrm{Ca}$ absorption by plants. The high concentration of $\mathrm{K}$ and $\mathrm{Mg}$ in the cassava wastewater (Table 2) probably contributed to the low absorption of Ca due to the competition between these nutrients during the process of absorption, as mentioned by Andreotti et al. (2000), which promoted antagonism between the nutrients.

Imbalance in the absorption of $\mathrm{Ca}$ and $\mathrm{Mg}$ was also observed by Salvador et al. (2011), who reported that the absorption of nutrients by soybean plants was compromised by the excessive presence of the other. These authors comment that the $\mathrm{Ca}: \mathrm{Mg}$ relationships most favorable to maintaining these nutrients in the plants were $1: 1$ and 3:1; on the other hand, the $\mathrm{Ca}: \mathrm{Mg}$ relationships most harmful to $\mathrm{Ca}$ absorption were $0: 1$ and 1:10, corroborating the responses obtained in the present study, whose $\mathrm{Ca}: \mathrm{Mg}$ relationship was equal to $1: 8$, thus very close to that found by the previously mentioned study.

Studying the effect of cassava wastewater on corn fertilization, Ribas et al. (2010) also observed that the application of the organic residue caused inhibition in the absorption of $\mathrm{Ca}$ and $\mathrm{Mg}$ by the plants during the initial development stage.

Simonete et al. (2003), evaluating the effect of another organic residue on corn growth and nutrition, reported that the amounts of $\mathrm{Ca}$ and $\mathrm{Mg}$ accumulated by plants increased with the application of the residue; however, the complementation with $\mathrm{K}$ fertilization decreased the absorption of $\mathrm{Ca}$ and $\mathrm{Mg}$ by plants, thus evidencing, as observed in the present study, the antagonism of $\mathrm{K}$ when in high concentrations in relation to the absorption of $\mathrm{Ca}$ and $\mathrm{Mg}$ by corn plants. According to Malavolta et al. (1997), high K concentrations in the soil solution may inhibit competitively the absorption of $\mathrm{Ca}$, and especially $\mathrm{Mg}$, by plant roots. As to $\mathrm{Na}$, despite the significant effect observed only for the isolated factor (age of plants after emergence), no regression model fitted to the data. This behavior of $\mathrm{Na}$ contents in the leaves and stalks of corn plants as a function of cassava wastewater doses applied in the soil was probably due to the high contents of $\mathrm{K}\left(4,793.90 \mathrm{mg} \mathrm{L}^{-1}\right)$ and 
$\mathrm{Mg}\left(1,588.20 \mathrm{mg} \mathrm{L}^{-1}\right)$ contained in the cassava wastewater used in the present study (Table 2), compared with the low content of $\mathrm{Na}\left(742 \mathrm{mg} \mathrm{L}^{-1}\right)$ in the residue (Table 2) and, consequently, the lower $\mathrm{Na}$ absorption by plants.

\section{Conclusions}

1. The increment in the cassava wastewater doses applied to the soil increased the contents of N, P and $\mathrm{K}$ in plant shoots and decreased the absorption of $\mathrm{Ca}$ and $\mathrm{Mg}$.

2. The contents of $\mathrm{N}, \mathrm{P}$ and $\mathrm{K}$ in the leaves and $\mathrm{K}$ in the stalks of corn plants, at $20 \mathrm{DAE}$, were higher than those at 40 and 52 DAE.

3. The highest contents of $\mathrm{P}$ and $\mathrm{K}$ in the stalks were observed at 40 DAE.

\section{Literature Cited}

Andreotti, M.; Souza, E. C. A.; Crusciol, C. A. C.; Rodrigues, J. D.; Büll, L. T. Produção de matéria seca e absorção de nutrientes pelo milho em razão da saturação por bases e da adubação potássica. Pesquisa Agropecuária Brasileira, v.35, p.2437-2446, 2000. http:// dx.doi.org/10.1590/S0100-204X2000001200015

APHA - American Public Health Association, AWWA - American Water Works Association, WPCF - Washington Press Club Foundation. Standard methods for the examination of water and wastewater. Washington: American Public Health Association, 17.ed. 1995. 2198p.

Bezerra Neto, E.; Barreto, L. P. Análises químicas e bioquímicas em plantas. Recife: UFRPE, 2011. 148p.

Borin, A. L. D. C.; Lana, R. M. Q.; Pereira, H. S. Absorção, acúmulo e exportação de macronutrientes no milho doce cultivado em condições de campo. Revista Ciência e Agrotecnologia, v.34, p.1591-1597, 2010. http://dx.doi.org/10.1590/S141370542010000700001

Costa, M. S.; Costa, Z. V. B.; Alves, S. M. C.; Ferreira Neto, M.; Marinho, M. J. C. Avaliação nutricional do milho cultivado com diferentes doses de efluente doméstico tratado. Irriga, v.1, p.12-26, 2012. http://dx.doi.org/10.15809/irriga.2012v1n01p12

Damasceno, A. P. A. B.; Medeiros, J. F.; Medeiros, D. C.; Melo, I. G. C.; Dantas, D. C. Crescimento e marcha de absorção de nutrientes do melão cantaloupe tipo "harper" fertirrigado com doses de $\mathrm{N}$ e K. Caatinga, v.25, p.137-146, 2012.

Duarte, A. S. Silva, E. F. F.; Rolim, M. M.; Ferreira, R. F. A. L.; Malheiros, S. M. M.; Albuquerque, F. S. Uso de diferentes doses de manipueira na cultura da alface em substituição à adubação mineral. Revista Brasileira de Engenharia Agrícola e Ambiental, v.16, p.262-267, 2012. http://dx.doi.org/10.1590/S1415-43662012000300005

EMBRAPA - Empresa Brasileira de Pesquisa Agropecuária. Manual de análises químicas de solos, plantas e fertilizantes. 2.ed. Brasília: EMBRAPA, 2009. 627p.

Erthal, V. J. T.; Ferreira, P. A.; Pereira, O. G.; Matos, A. T. Características fisiológicas, nutricionais e rendimento de forrageiras fertigadas com água residuária de bovinocultura. Revista Brasileira de Engenharia Agrícola e Ambiental, v.14, p.458-466, 2010. http:// dx.doi.org/10.1590/S1415-43662010000500002

Fancelli, A. L.; Dourado Neto, D. Produção de milho. Guaíba: Agropecuária, 2000. 360p.
Gomes, S. B. V.; Nascimento, W. A.; Biondi, C. M. Produtividade e composição mineral de plantas de milho em solo adubado com lodo de esgoto. Revista Brasileira de Engenharia Agrícola e Ambiental, v.11, p.459-465, 2007. http://dx.doi.org/10.1590/ S1415-43662007000500002

Goto, R.; Guimarães, V. F.; Echer, M. M. Aspectos fisiológicos e nutricionais no crescimento e desenvolvimento de plantas hortícolas. In: Folegatti, M. V.; Casarini, E.; Blanco, F. F.; Brasil, R. P. C.; Resende, R. S. (coord.). Fertirrigação: Flores, frutas e hortaliças, Guaíba: Agropecuária, v.2, p.241-268, 2001.

Inoue, K. R. A.; Souza, C. F.; Matos, A. T.; Santos, N. T.; Ferreira, W. P. M. Concentração de nutrientes em plantas de milho, adubadas com biofertilizantes, obtidos na digestão anaeróbia da manipueira. Revista Engenharia na Agricultura, v.19, p.236-243, 2011. http:// dx.doi.org/10.13083/1414-3984.v19n03a06

IPA - Instituto Agronômico de Pernambuco. Recomendações de adubação para o Estado de Pernambuco. Recife: IPA, 2008. 64p.

Laufenberg, G.; Kunz, B.; Nystrom, M. Transformation of vegetable waste into value added products: the upgrading concept; practical implementations. Bioresource Technology, v.87, p.167-198, 2003. http://dx.doi.org/10.1016/S0960-8524(02)00167-0

Magalhães, A. G. Desenvolvimento e produção do milho e alterações químicas em diferentes solos com aplicação de manipueira. Recife: UFRPE, 2013. 100p. Tese Doutorado

Malavolta, E.; Vitti, G. C.; Oliveira, S. A. Avaliação do estado nutricional de plantas: Princípios e aplicações. Piracicaba: Potafós, 1997. 308p.

Morrill, W. B. B.; Rolim, M. M.; Bezerra Neto, E.; Pedrosa, E. M. R.; Oliveira, V. S.; Almeida, G. L. P. Produção e nutrientes minerais de milheto forrageiro e sorgo sudão adubado com soro de leite. Revista Brasileira Engenharia Agrícola e Ambiental, v.16, p.182-188, 2012. http://dx.doi.org/10.1590/S141543662012000200008

Pinho, R. G. von; Borges, I. D.; Andrade, J. L.; Pereira, R.; Reis, M. C. Marcha de absorção de macronutrientes e acúmulo de matéria seca em milho. Revista Brasileira de Milho e Sorgo, v.8, p.157-173, 2009. http://dx.doi.org/10.18512/1980-6477/ rbms.v8n2p157-173

Ribas, M. M. F.; Cereda, M. P.; Villas Bôas, R. L. Use of cassava wastewater treated anaerobically with alkaline agents as fertilizer for maize (Zea mays L.). Brazilian Archives of Biology and Technology, v.53, p.55-62, 2010. http://dx.doi.org/10.1590/S151689132010000100007

Rodrigues, M. A. C.; Buzetti, S.; Teixeira Filho, M. C. M.; Garcia, C. M. P.; Andreotti, M. Adubação com $\mathrm{KCl}$ revestido na cultura do milho no Cerrado. Revista Brasileira de Engenharia e Ambiental, v.18, p.127-133, 2014. http://dx.doi.org/10.1590/ S1415-43662014000200001

Salvador, J. T.; Carvalho, T. C.; Lucchesi, L. A. C. Relações cálcio e magnésio presentes no solo e teores foliares de macronutrientes. Revista Acadêmica: Ciências Agrárias e Ambientais, v.9, p.2732, 2011.

Sangoi, L.; Ernani, P. R.; Bianchet, P.; Vargas, V. P.; Picoli, G. J. Efeito de doses de cloreto de potássio sobre a germinação e o crescimento inicial do milho, em solos com texturas contrastantes. Revista Brasileira de Milho e Sorgo, v.8, p.187-197, 2009. http://dx.doi. org/10.18512/1980-6477/rbms.v8n2p187-197 
Saraiva, F. Z.; Sampaio, S. C.; Silvestre, M. G.; Queiroz, M. M. F.; Nóbrega, L. H. P.; Gomes, B. M. Uso de manipueira no desenvolvimento vegetativo do milho em ambiente protegido. Revista Brasileira de Engenharia Agrícola e Ambiental, v.11, p.3036, 2007. http://dx.doi.org/10.1590/S1415-43662007000100004

Silva Júnior, J. J.; Coelho, E. F.; Santana, J. A. V.; Santana Júnior, E. B.; Pamponet, A. J. M. Uso da manipueira na bananeira 'terra maranhão' e seus efeitos no solo e na produtividade. Irriga, v.17, p.353-363, 2012.
Simonete, M. A.; Kiehl, J. C.; Andrade, C. A.; Teixeira, C. F. A. Efeito do lodo de esgoto em um Argissolo e no crescimento e nutrição de milho. Pesquisa Agropecuária Brasileira, v.38, p.1187-1195, 2003. http://dx.doi.org/10.1590/S0100-204X2003001000008

Ueno, R. K.; Neumann, M.; Marafon, F.; Basi, S.; Rosário, J. G. Dinâmica dos nutrientes do solo em áreas destinadas à produção de milho para forragem. Revista Brasileira de Tecnologia Aplicada nas Ciências Agrárias, v.4, p.182-203, 2011. 